\title{
Stool sample storage conditions for the preservation of Giardia intestinalis DNA
}

\author{
Salih Kuk, Suleyman Yazar/ ${ }^{+}$, Ulfet Cetinkaya \\ Department of Parasitology, Medical Faculty, Erciyes University, Kayseri, Turkey
}

Stool is chemically complex and the extraction of DNA from stool samples is extremely difficult. Haemoglobin breakdown products, such as bilirubin, bile acids and mineral ions, that are present in the stool samples, can inhibit DNA amplification and cause molecular assays to produce false-negative results. Therefore, stool storage conditions are highly important for the diagnosis of intestinal parasites and other microorganisms through molecular approaches. In the current study, stool samples that were positive for Giardia intestinalis were collected from five different patients. Each sample was stored using one out of six different storage conditions [room temperature (RT), $+4^{\circ} \mathrm{C},-20^{\circ} \mathrm{C}, 70 \%$ alcohol, $10 \%$ formaldehyde or $2.5 \%$ potassium dichromate] for DNA extraction procedures at one, two, three and four weeks. A modified QIAamp Stool Mini Kit procedure was used to isolate the DNA from stored samples. After DNA isolation, polymerase chain reaction (PCR) amplification was performed using primers that target the $\beta$-giardin gene. A G. intestinalis-specific $384 \mathrm{bp}$ band was obtained from all of the cyst-containing stool samples that were stored at $R T,+4^{\circ} \mathrm{C}$ and $-20^{\circ} \mathrm{C}$ and in $70 \%$ alcohol and $2.5 \%$ potassium dichromate; however, this band was not produced by samples that had been stored in $10 \%$ formaldehyde. Moreover, for the stool samples containing trophozoites, the same G. intestinalis-specific band was only obtained from the samples that were stored in $2.5 \%$ potassium dichromate for up to one month. As a result, it appears evident that the most suitable storage condition for stool samples to permit the isolation of $\mathrm{G}$. intestinalis DNA is in $2.5 \%$ potassium dichromate; under these conditions, stool samples may be stored for one month.

Key words: Giardia intestinalis - DNA isolation - storage conditions - stool

Giardia intestinalis (syn. Giardia lamblia, Giardia duodenalis) is the most common intestinal protozoan in the world. This parasite can infect humans and a variety of other members of the animal kingdom, including mammalian, avian and reptilian species (Thompson 2002, Appelbee et al. 2005). The life cycle of $G$. intestinalis includes two different forms: the infective cyst, which is resistant to many environmental conditions, and the trophozoite, which colonises the intestinal lumen, but does not invade the mucosa (Eckmann \& Gillin 2001). G. intestinalis are shed as cysts in faeces and the faecal-oral route is the main path of infection for this parasite. Contaminated water, food and fomites are generally effective vehicles for transmitting the infection. The traditional microscopy of stool samples, direct fluorescent antibody tests and enzyme-linked immunosorbent assays are still commonly used techniques for the diagnosis of giardiasis. However, the sensitivity of these methods may be inadequate for detecting low levels of infection (Johnston et al. 2003, Nantavisai et al. 2007), identifying different $G$. intestinalis genotypes or assemblages or discriminating among genetic variations of $G$. intestinalis (Amar et al. 2004, Bertrand et al. 2005).

The isolation of DNA from samples is often an early and routine step in many analytical processes, such as the

+ Corresponding author: syazar@erciyes.edu.tr

Received 25 October 2011

Accepted 21 August 2012 detection of bacteria, viruses, fungi and parasites, the diagnosis of diseases or genetic disorders, forensic investigation and historical identification (Van Belkum \& Hays 2008). DNA extraction is the separation of DNA from any type of cell or sample for a particular purpose. DNA extraction follows a series of steps. In particular, the DNA extraction begins with the lysis of the cell that contains the DNA of interest; this lysis is followed first by the removal of all proteins from the DNA and then by the final step of precipitating the DNA (Van Belkum \& Hays 2008). DNA is normally obtained from samples of skin, tissue, cerebrospinal fluid, blood, urine, sputum, stool, or formalin-fixed embedded tissue. However, stool samples have a particularly complex structure. DNA isolation from stool samples is hampered by the inhibitory compounds that are present in faeces, which include the degradation products of haemoglobin, bilirubin, bile acids and mineral ions. Frequently, stool samples can produce failed attempts to isolate DNA and false-negative amplification reactions (Kostrzynska et al. 1999, Nantavisai_et al. 2007).

Storage time and conditions are also important factors in the isolation of DNA from stool samples. The DNA of trophozoites, which are particularly vulnerable to environmental factors, can rapidly degenerate. Therefore, either DNA from fresh stool should be extracted as quickly as possible, or the stool in question should be appropriately stored. Stool storage conditions are highly important for the use of molecular approaches to diagnosing intestinal parasites and other microorganisms. The objective of this work was to determine the best storage conditions for the isolation of DNA from stool samples containing $G$. intestinalis. 


\section{SUBJECTS, MATERIALS AND METHODS}

Samples and storage conditions - In this study, $G$. intestinalis-positive stool samples were collected from five different patients at the Erciyes University Faculty of Medicine and Department of Medical Parasitology; these patients volunteered to participate in this study. Three of the stool samples that were obtained contained more Giardia cysts than Giardia trophozoites, whereas the remaining two samples contained more Giardia trophozoites than cysts. A $200 \mathrm{mg} \mathrm{G}$. intestinalis-positive stool sample was divided into 24 portions and each sample was stored at one of six different conditions [room temperature (RT), $+4^{\circ} \mathrm{C},-20^{\circ} \mathrm{C}, 70 \%$ alcohol, $10 \%$ formaldehyde or $2.5 \%$ potassium dichromate] for DNA extraction at one, two, three and four weeks of storage.

DNA isolation - Before the DNA isolation was performed, the stool samples were washed three times in sterile distilled water. In accordance with the manufacturer's instructions, a modified QIAamp Stool Mini Kit (Qiagen, USA) was used to isolate DNA from the stored samples. All of the centrifugation steps were performed at RT $\left(20-25^{\circ} \mathrm{C}\right)$ and $14,000 \mathrm{rpm}$. A quantity of $1.4 \mathrm{~mL}$ of ASL buffer was added to the washed stool samples, which were then heated at $95^{\circ} \mathrm{C}$ for $5 \mathrm{~min}$. Subsequently, $100 \mu \mathrm{L}$ of buffer $\mathrm{AE}$ was directly pipetted onto the membrane of the QIAamp spin column and the column and buffer were incubated for $2 \mathrm{~min}$ at RT. The resulting DNA was eluted, centrifuged twice at full speed and then stored at $-20^{\circ} \mathrm{C}$ until it was used in the polymerase chain reaction (PCR) amplifications.

$P C R$ - Prior to the PCR amplifications, the DNA concentration of each sample was measured using a Nanodrop (ACTGene ASP-3700, USA) instrument. After this measurement, PCR was performed with primers that targeted the $\beta$-giardin (bg) gene; in particular, these primers were known as G367 (5'CATAACGACGCCATCGCGGCTCT CAGGAA3') and G759 (5'GAGGCCGCCCTGGATCTT CGAGACGAC3') (Cacciò et al. 2002). The PCR amplifications were each performed in a $25 \mu \mathrm{L}$ volume that contained $12.5 \mu \mathrm{L}$ 2x PCR Master mix (Vivantis, Malaysia), $2 \mu \mathrm{L}$ of each primer (at $20 \mathrm{pmol}$ ) and $5 \mu \mathrm{L}$ of genomic template DNA. These reactions were performed in a PCR Labcycler (SENSQUEST, Germany). The following PCR cycle was used: an initial denaturation at $95^{\circ} \mathrm{C}$ for $5 \mathrm{~min}$, 35 subsequent cycles of denaturation at $94^{\circ} \mathrm{C}$ for $30 \mathrm{sec}$, annealing at $65^{\circ} \mathrm{C}$ for $30 \mathrm{sec}$ and extension at $72^{\circ} \mathrm{C}$ for $1 \mathrm{~min}$ and a final extension at $72^{\circ} \mathrm{C}$ for $7 \mathrm{~min}$. Negative controls for the amplification reaction mixtures that contained only the PCR reaction reagents and sterile distilled water were prepared. PCR products from all of the amplifications were visualised by electrophoresis on a $1.5 \%$ agarose gel containing ethidium bromide.

\section{RESULTS}

DNA was isolated from all of the stool samples and analysed with a Nanodrop instrument prior to PCR amplification (Table I) and the samples that contained a minimum DNA concentration were stored in $10 \%$ formaldehyde. For stool samples that contained more Giardia cysts than trophozoites, storage in $10 \%$ formaldehyde for one day or longer resulted in the absence of $G$. intestinalis; however, a G. intestinalis-specific 384 bp band was obtained from all of the stool samples with cysts that were stored at RT, at $+4^{\circ} \mathrm{C}$, at $-20^{\circ} \mathrm{C}$, in $70 \%$ alcohol or in $2.5 \%$ potassium dichromate for a month (Figure, Table II).

Two samples contained more Giardia trophozoites than cysts. The $G$. intestinalis-specific 384 bp band was obtained from all of the stool samples that were stored in $2.5 \%$ potassium dichromate. The presence of $G$. intestinalis DNA was not observed in the stool samples that had been stored for one, two, three or four weeks in any of the other examined conditions (Figure, Table II).

\section{DISCUSSION}

Compared with the genotyping methods that are available for other protozoan pathogens, the existing genotyping techniques for Giardia spp are not particularly advanced. The small subunit ribosomal RNA (ssurRNA), bg, glutamate dehydrogenase, elongation factor 1-alpha, triose phosphate isomerase and GLORF-C4 genes (Cacciò \& Ryan 2008) have been used for Giardia spp genotype analysis; recently, the inter-genomic rRNA spacer region has also been utilised for this purpose (Lee et al. 2006). Among the aforementioned genes, two of the most commonly used regions for genotype analysis are the small ssu-rRNA and the bg (Faubert 2000, Cacciò et al. 2002).

TABLE I

DNA concentration $(\mathrm{ng} / \mu \mathrm{L})$ before polymerase chain reaction according to storage condition and duration

\begin{tabular}{lcccc}
\hline Storage condition & $\begin{array}{c}\text { First week } \\
\text { min.-max.(average } \pm \text { SD) }\end{array}$ & $\begin{array}{c}\text { Second week } \\
\text { min.-max.(average } \pm \text { SD) }\end{array}$ & $\begin{array}{c}\text { Third week } \\
\text { min.-max.(average } \pm \text { SD) }\end{array}$ & $\begin{array}{c}\text { Fourth week } \\
\text { min.-max.(average } \pm \text { SD) }\end{array}$ \\
\hline Room temperature & $27-158.8(63.54 \pm 55.8)$ & $58.7-160.7(69.9 \pm 53.4)$ & $5.7-68.5(69.8 \pm 64.8)$ & $15.3-83.4(58.5 \pm 37.6)$ \\
$+4^{\circ} \mathrm{C}$ & $52-146(86.8 \pm 50.9)$ & $64.9-136.7(89.4 \pm 49)$ & $12.6-121.5(81.4 \pm 59.9)$ & $92.3-150(125.7 \pm 29.9)$ \\
$-20^{\circ} \mathrm{C}$ & $27-198(86.6 \pm 84.4)$ & $72.6-199.8(94.4 \pm 80.5)$ & $10.5-137.1(74.5 \pm 63.3)$ & $77.4-176(131.5 \pm 49.9)$ \\
$70 \%$ alcohol & $8.9-226.9(108.9 \pm 108.6)$ & $176.4-225.7(139.4 \pm 99.8)$ & $10.5-178(119.5 \pm 94.4)$ & $137.5-535(282.6 \pm 219.4)$ \\
$10 \%$ formaldehyde & $1.6-14.8(8.7 \pm 6.6)$ & $1.3-5.4(5.4 \pm 4.2)$ & $3.8-5.5(3.6 \pm 1.9)$ & $5.4-8.3(6.4 \pm 1.6)$ \\
$2.5 \%$ potassium dichromate & $22.6-82.3(48.7 \pm 24.2)$ & $33-82.8(52.3 \pm 21.6)$ & $17-52.8(40.7 \pm 15)$ & $20-52.3(36.9 \pm 15.3)$ \\
\hline
\end{tabular}

SD: standard deviation. 
Because sequences of the Giardia ssrRNA gene have an unusually high GC content, the amplification of the Giardia ssrRNA gene presents technical problems. Moreover, the ssrRNA assay can lack the desired specificity; the use of certain primers has resulted in the amplification of DNA from protozoa that are totally unrelated to Giardia (Weiss et al. 1992). The amplification of the $b g$ gene is highly specific and no cross-amplification was observed to result from using host, protozoan, fungal, algal or bacterial DNA as templates for PCR amplification. The giardin genes that encode al-giardin, $\alpha 2$-giardin, bg and $\gamma$-giardin have been cloned and used for PCR amplification and genotyping (Aggarwal_et al. 1989, Alonso \& Peattie 1992, Nohria et al. 1992). Volotão et al. (2007) investigated a total of 87 stool samples and reported that 62 isolates could be amplified through the use of the $b g$ gene for both short and long fragments. Because of these bg-related advantages, the 384 bp bg gene fragment was used in this study as an indicator of the presence of $G$. intestinalis DNA.

Although many methods are available for the diagnosis of $G$. intestinalis, molecular approaches must be developed because these techniques will permit greater diagnostic sensitivity and allow for different $G$. intestinalis genotypes to be distinguished. However, because the basis of molecular methods is DNA extraction, an effective DNA isolation procedure is important for improving the sensitivity of molecular methods. The choice of appropriate samples and sample storage conditions is very important for DNA isolation. In particular, to ensure the effective isolation of DNA from stool samples, these samples must be stored properly. In this study, each examined stool sample was stored under one of six different conditions prior to DNA extractions that were performed over the course of one month. It has been demonstrated that for stool samples containing both cysts and trophozoites, the most suitable storage condition for the isolation of DNA from G. intestinalis is the use of 2.5\% potassium dichromate. Samples can be stored for one month. Trophozoite structures that are susceptible to environmental conditions may be rapidly damaged at RT, $+4^{\circ} \mathrm{C}$, or $-20^{\circ} \mathrm{C}$. In addition, although the presence of $G$. intestinalis DNA was not observed in stool samples that

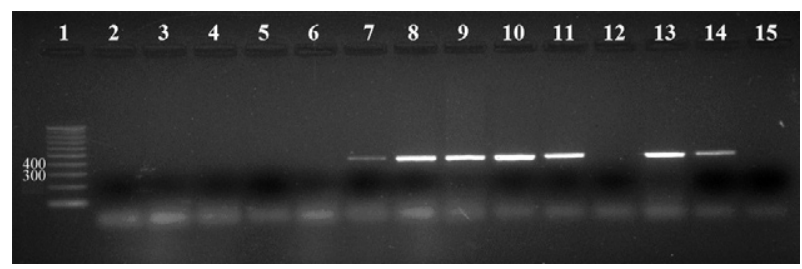

Agarose gel showing amplifications of polymerase chain reaction of Giardia intestinalis which were stored six different conditions. Lane 1: 100 bp Plus DNA Ladder (Vivantis); 2-7: sample contain more Giardia trophozoites than Giardia cyst; 8-13: sample contain only Giardia cyst; 2, 8: from sample stored at room temperature; 3, 9: from sample stored at $+4^{\circ} \mathrm{C} ; 4,10$ : from sample stored at $-20^{\circ} \mathrm{C} ; 5,11$ : from sample stored at $70 \%$ alcohol; 6,12 : from sample stored at $10 \%$ formaldehyde; 7 , 13: from sample stored at $2.5 \%$ potassium dichromate; 14 : positive control; 15: negative control. contained more trophozoites than cysts and were stored in $70 \%$ alcohol, a $G$. intestinalis-specific $384 \mathrm{bp}$ band was obtained from stool samples containing cysts that were stored in $70 \%$ alcohol. It is known that the $\mathrm{pH}$ levels of $2.5 \%$ potassium dichromate and $70 \%$ alcohol are 4 and 8.3 , respectively. We suggest that the $\mathrm{pH}$ or another factor may affect the success of DNA isolation procedures from trophozoite-containing stool samples.

Wilke and Robertson (2009) collected seven samples containing Giardia cysts and stored these samples under four different conditions (phosphate buffered saline, $5 \%$ potassium dichromate, $4 \%$ formaldehyde and ethanol). These researchers used real-time PCR to assess seven different samples over a period of three months and stated that their best results with respect to DNA isolation were obtained from samples that had been stored in ethanol or potassium dichromate at $4^{\circ} \mathrm{C}$. In another study, a total of 70 samples (from 60 humans and 10 animals) were stored in $5-10 \%$ formaldehyde (the duration of this storage was unclear from the published report of the investigation); these samples were examined and only 44 (from $43 \mathrm{hu}$ mans and 1 animal) isolates could be amplified from these samples (Minvielle et al. 2008). In addition, Pelayo et al. (2008) investigated a total of 95 samples that were

\section{TABLE II}

Storage duration and condition for DNA isolation of Giardia intestinalis

\begin{tabular}{|c|c|c|c|c|c|c|}
\hline \multirow[b]{2}{*}{ Duration } & \multirow[b]{2}{*}{ Storage condition } & \multicolumn{5}{|c|}{ Number of samples } \\
\hline & & $1^{a}$ & $2^{a}$ & $3^{a}$ & $4^{b}$ & $5^{b}$ \\
\hline \multirow[t]{6}{*}{ First week } & Room temperature & + & + & + & - & - \\
\hline & $+4^{\circ} \mathrm{C}$ & + & + & + & - & - \\
\hline & $-20^{\circ} \mathrm{C}$ & + & + & + & - & - \\
\hline & $70 \%$ alcohol & + & + & + & - & - \\
\hline & $10 \%$ formaldehyde & - & - & - & - & - \\
\hline & $2.5 \%$ potassium dichromate & + & + & + & + & + \\
\hline \multirow[t]{6}{*}{ Second week } & Room temperature & + & + & + & - & - \\
\hline & $+4^{\circ} \mathrm{C}$ & + & + & + & - & - \\
\hline & $-20^{\circ} \mathrm{C}$ & + & + & + & - & - \\
\hline & $70 \%$ alcohol & + & + & + & - & - \\
\hline & $10 \%$ formaldehyde & - & - & - & - & - \\
\hline & $2.5 \%$ potassium dichromate & + & + & + & + & + \\
\hline \multirow[t]{6}{*}{ Third week } & Room temperature & + & + & + & - & - \\
\hline & $+4^{\circ} \mathrm{C}$ & + & + & + & - & - \\
\hline & $-20^{\circ} \mathrm{C}$ & + & + & + & - & - \\
\hline & $70 \%$ alcohol & + & + & + & - & - \\
\hline & $10 \%$ formaldehyde & - & - & - & - & - \\
\hline & $2.5 \%$ potassium dichromate & + & + & + & + & + \\
\hline \multirow[t]{6}{*}{ Fourth week } & Room temperature & + & + & + & - & - \\
\hline & $+4^{\circ} \mathrm{C}$ & & + & + & - & - \\
\hline & $-20^{\circ} \mathrm{C}$ & + & + & + & - & - \\
\hline & $70 \%$ alcohol & + & + & + & - & - \\
\hline & $10 \%$ formaldehyde & - & - & - & - & - \\
\hline & $2.5 \%$ potassium dichromate & + & + & + & + & + \\
\hline
\end{tabular}

a: sample contain more Giardia cyst than Giardia trophozoites; $b$ : sample contain more Giardia trophozoites than Giardia cyst. 
stored at $-20^{\circ} \mathrm{C}$ in $70 \%$ ethanol for up to 20 months and reported that just 20 isolates could be amplified from their samples. It has been demonstrated that from a total of 147 samples that were stored at $4^{\circ} \mathrm{C}$ without preservatives (the duration of this storage was not clearly specified in published reports), only 92 isolates could be amplified (Gómez-Couso et al. 2012). Singh et al. (2009) investigated 45 samples that were stored at $-20^{\circ} \mathrm{C}$ without preservatives (the duration of this storage was not clearly specified in the published report of this investigation) and observed that only 35 isolates could be amplified from these samples following the storage. Peréz Cordón et al. (2008) also investigated 210 samples that were stored in $2.5 \%$ potassium dichromate at $+4^{\circ} \mathrm{C}$ without preservatives (the duration of this storage was unclear from the published report of this study) and reported that only 16 isolates could be amplified from these samples. Although many of the aforementioned papers had unclear storage times, several of these papers mentioned long storage periods. Samples are generally stored for one month for epidemiological studies. Therefore, our study studied storage times of up to one month.

The efficiency of nested PCR in diagnosing cryptosporidiosis in fresh and formalin-preserved faecal samples has been evaluated in a previously published study. The sensitivity and specificity of this method for assessing fresh and formalin-preserved samples were found to be $100 \%$ and $50 \%$, respectively; this result indicated that small quantities of formaldehyde in the samples were inhibiting the PCR reaction, possibly producing false-negative results (Dirim et al. 2009). Thus, in this study, it has been demonstrated that during the course of a storage period of one month, $2.5 \%$ potassium dichromate is the most suitable of the examined storage conditions for isolating $G$. intestinalis DNA from stool samples. This study suggests that different forms of microorganisms and other parasites from stool samples should be assessed separately for samples that are stored for longer than one month.

\section{REFERENCES}

Aggarwal A, Adam RD, Nash TE 1989. Characterization of a 29.4kilodalton structural protein of Giardia lamblia and localization to the ventral disk. Infect Immun 57: 1305-1310.

Alonso RA, Peattie DA 1992. Nucleotide sequence of a second alpha giardin gene and molecular analysis of the alpha giardin genes and transcripts in Giardia lamblia. Mol Biochem Parasitol 50: 95-104.

Amar CF, East C, Maclure E 2004. Blinded application of microscopy, bacteriological culture, immunoassays and PCR to detect gastrointestinal pathogens from faecal samples of patients with community-acquired diarrhoea. Eur J Clin Microbiol Infect Dis 23: 529-534.

Appelbee AJ, Thompson RC, Olson ME 2005. Giardia and Cryptosporidium in mammalian wildlife - current status and future needs. Trends Parasitol 21: 370-376.

Bertrand I, Albertini L, Schwartzbrod J 2005. Comparison of two target genes for detection and genotyping of Giardia lamblia in human feces by PCR and PCR-restriction fragment length polymorphism. J Clin Microbiol 43: 5940-5944.

Cacciò SM, De Giacomo M, Pozio E 2002. Sequence analysis of the beta-giardin gene and development of a polymerase chain reaction-restriction fragment length polymorphism assay to genotype
Giardia duodenalis cysts from human faecal samples. Int J Parasitol 32: 1023-1030.

Cacciò SM, Ryan U 2008. Molecular epidemiology of giardiasis. Mol Biochem Parasitol 160: 75-80.

Dirim ED, Dağci H, Turgay N 2009. The molecular diagnosis of cryptosporidiosis in fresh and formalin preserved fecal samples. Türkiye Parazitol Derg 33: 120-124.

Eckmann L, Gillin FD 2001. Microbes and microbial toxins: paradigms for microbial-mucosal interactions. I. Pathophysiological aspects of enteric infections with the lumen-dwelling protozoan pathogen Giardia lamblia. Am J Physiol Gastrointest Liver Physiol 280: 1-6.

Faubert G 2000. Immune response to Giardia duodenalis. Clin Microbiol Rev 13: 35-54.

Gómez-Couso H, Ortega-Mora LM, Aguado-Martínez A, Rosadio-Alcántara R, Maturrano-Hernández L, Luna-Espinoza L, Zanabria-Huisa V, Pedraza-Díaz S 2012. Presence and molecular characterisation of Giardia and Cryptosporidium in alpacas (Vicugna pacos) from Peru. Vet Parasitol 187: 414-420.

Johnston SP, Ballard MM, Beach MJ 2003. Evaluation of three commercial assays for detection of Giardia and Cryptosporidium organisms in fecal specimens. J Clin Microbiol 41: 623-626.

Kostrzynska M, Sankey M, Haack E 1999. Three sample preparation protocols for polymerase chain reaction based detection of Cryptosporidium parvum in environmental samples. $J$ Microbiol Methods 35: 65-71.

Lee H, Lee J, Park S 2006. Detection and genotyping of Giardia intestinalis isolates using intergentic spacer (IGS) based PCR. Korean J Parasitol 44: 343-353.

Minvielle MC, Molina NB, Polverino D, Basualdo JA 2008. First genotyping of Giardia lamblia from human and animal feces in Argentina, South America. Mem Inst Oswaldo Cruz 103: 98-103.

Nantavisai K, Mungthin M, Tan-ariya P 2007. Evaluation of the sensitivities of DNA extraction and PCR methods for detection of Giardia duodenalis in stool specimens. J Clin Microbiol 45: 581-583.

Nohria A, Alonso RA, Peattie DA 1992. Identification and characterization of gamma-giardin and the gamma-giardin gene from Giardia lamblia. Mol Biochem Parasitol 56: 27-37.

Pelayo L, Nuñez FA, Rojas L 2008. Giardia infections in Cuban children: the genotypes circulating in a rural population. Ann Trop Med Parasitol 102: 585-595.

Peréz Cordón G, Cordova Paz Soldan O, Vargas Vásquez F 2008. Prevalence of enteroparasites and genotyping of Giardia lamblia in Peruvian children. Parasitol Res 103: 459-465.

Singh A, Janaki L, Petri WA JR 2009. Giardia intestinalis assemblages A and B infections in Nepal. Am J Trop Med Hyg 81: 538-539.

Thompson RC 2002. Presidential address: rediscovering parasites using molecular tools-towards revising the taxonomy of Echinococcus, Giardia and Cryptosporidium. Int J Parasitol 32: 493-496.

Van Belkum A, Hays JP 2008. Technical aspects and principles of PCR amplification, Springer Science+Business Media BV, Dordrecht, $330 \mathrm{pp}$.

Volotão AC, Costa-Macedo LM, Haddad FS 2007. Genotyping of Giardia duodenalis from human and animal samples from Brazil using beta-giardin gene: a phylogenetic analysis. Acta Trop 102: 10-19.

Weiss JB, van Keulen H, Nash TE 1992. Classification of subgroups of Giardia lamblia based upon ribosomal RNA gene sequence using the polymerase chain reaction. Mol Biochem Parasitol 54: 73-86.

Wilke H, Robertson LJ 2009. Preservation of Giardia cysts in stool samples for subsequent PCR analysis. J Microbiol Methods 78: 292-296. 